J. Lake Sci. (湖泊科学), 2011, 23(4):612-618

http: //www.jlakes.org. E-mail: jlakes@niglas. ac.cn

(c) 2011 by Journal of Lake Sciences

\title{
贵州百花湖麦西河河口浮游植物群落结构及与环境因子关系*
}

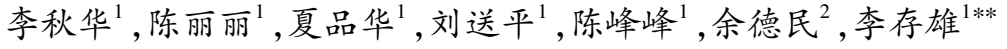 \\ $(1$ : 贵州师范大学贵州省山地环境信息系统和生态环境保护重点实验室,贵阳 550001) \\ $(2$ : 湖南理工学院数学学院, 岳阳 414000$)$
}

\begin{abstract}
摘 要: 2009 年 7 月至 2010 年 6 月, 以每月一次的频率对百花湖 (水库) 麦西河河口浮游植物群落结构和环境因子进行 调查. 监测到浮游植物 66 种 (属), 浮游植物主要由绿藻、硅藻和蓝藻组成, 夏秋季湖泊假鱼腥藻 ( Pseudanabaena limneti$c a$ ) 为优势浮游植物, 而冬春季梅尼小环藻 (Cyclotella meneghiniana) 为主要优势藻. 浮游植物丰度在 $1.17 \times 10^{4}-3.35 \times$ $10^{7} \mathrm{cells} / \mathrm{L}$ 之间, 2010 年 4 月最低, 2009 年 7 月最高, 浮游植物种群在 4-9 月主要由蓝藻组成, 冬季由硅藻和甲藻组成. 运用典型对应分析研究结果表明: 温度是影响麦西河河口浮游植物群落结构动态变化的最主要环境因子, 其次为营养 盐; 蓝藻的大部分种类和裸藻受水温和浊度等影响较大, 而硅藻和绿藻的大部分种类受氮磷营养盐浓度影响较大.
\end{abstract}

关键词: 浮游植物, 环境因子,典范对应分析,河口,水库

\section{Structure of phytoplankton community and its relationship with environmental factors at the estuary of Maixi River in Baihua Reservoir, Guizhou Province}

\author{
LI Qiuhua $^{1}$, CHEN Lili ${ }^{1}$, XIA Pinhua ${ }^{1}$, LIU Songping ${ }^{1}$, CHEN Fengfeng $^{1}$, YU Demin ${ }^{2}$ \& LI Cunxiong ${ }^{1}$ \\ (1: Key Laboratory for Information System of Mountainous Area and Protection of Ecological Environment of Guizhou Prov- \\ ince, Guizhou Normal University, Guiyang 550001, P. R. China) \\ (2: Department of Mathematics, Hunan Institute of Science and Technology, Yueyang 414000, P. R. China)
}

\begin{abstract}
Phytoplankton and environmental factors at the estuary of Maixi River in Baihua Reservoir were investigated monthly from July 2009 to June 2010. Results showed that there were 66 species (genus), which were mainly composed of the chlorophyta, bacillariophyta and cyanobacteria. The phytoplankton community was dominated by Pseudanabaena limnetica in summer and fall and by Cyclotella meneghiniana in winter and spring. The abundance of phytoplankton ranged from $1.17 \times 10^{4}$ to $3.35 \times 10^{7}$ cells/ L. The minimum phytoplankton abundance occurred in April of 2010 , and the maximum occurred in July of 2009 . The phytoplankton abundance composition was dominated mainly by cyanobacteria from April to September, but by bacillariophyta and pyrrophyta from October to March. Canonical correspondence analysis showed that temperature was the most important driving factor in regulating the composition and feature of phytoplankton community at the estuary. Nitrogen and phosphorus were the second important driving factors for the structure of phytoplankton community. Euglenophyta and a majority of cyanobacteria were affected by water temperature and turbidity, but chlorophyta and bacillariophyta were affected by the concentrations of nitrogen and phosphorus among these environmental factors.
\end{abstract}

Keywords: Phytoplankton; environmental factors; canonical correspondence analysis; estuary; reservoir

浮游植物是水域生态系统的重要组成部分, 也是生态系统中的主要初级生产者 ${ }^{[1]}$. 浮游植物群落结构 的变化直接影响着水质变化. 河口地区一般人口密集,生活污水或工业废水的排放使河口水域生态环境发 生了一定程度的改变, 浮游植物的数量和群落组成受到影响. 河口生态系统受多种因素的影响,包括水体的

* 贵州省科技厅社会发展攻关项目 (SZ[2009]3002)、贵阳市科技局社会发展攻关项目 ( [2009 ] 3 - 04) 和贵阳市重 大科技专项 ( [2010]5-03) 联合资助. 2010-11-05 收稿;2010-12-13 收修改稿. 李秋华, 男, 1977 年生, 博士, 副 教授;E-mail:qiuhua2002@126.com.

** 通讯作者;E-mail:1cx@gznu. edu.cn. 
物理、化学和生物特征以及水文特征等 ${ }^{[2]}$, 一般也是水华频繁发生的区域,其水质的好坏直接或间接影响着 水域的水质状况, 因而河口也成为当今湖沼学、环境科学、水域生态学研究的热点 ${ }^{[3-4]}$. 典型对应分析 (CCA) 因具有能同时结合多个环境因子,包含的信息量大,结果明确、直观、效果好等优点而受到重视. CCA 为分析 浮游植物群落与环境因子间的复杂关系提供了工具 ${ }^{[5-11]}$. 李秋华等对广东省大镜山水库的环境因子分析表 明, 温度和降雨成为影响浮游植物群落结构动态的主要驱动因子 ${ }^{[11]}$. 路娜等对巢湖浮游植物研究指出温度、 浊度和硝氮是影响巢湖水体浮游植物群落结构动态变化的主要环境因子 ${ }^{[12]}$, 邓建明等对洪湖浮游植物研究 指出水温、溶解氧和悬浮物是影响浮游植物群落结构动态的主要环境因子 ${ }^{[13]}$. 本文对贵州百花湖河口浮游 植物群落结构和环境因子之间的关系进行研究, 目的在于找出影响河口水质变化的主要环境因子, 为今后 河口水质改善和水资源的综合管理提供理论依据.

\section{1 材料与方法}

\section{1 采样点及频率}

百花湖 (水库) 位于贵阳西北郊, 是红枫湖 (水库) 的下游 湖库,于 1966 年建成, 坝高 $48.7 \mathrm{~m}$. 百花湖是猫跳河梯级电站 第二级蓄水库. 主要由红枫湖 (水库)下泄水以及长冲河、东门 桥河、麦城河和麦西河四源汇成. 麦西河是百花湖主要污染源 之一, 因而麦西河河口也是水质恶化相对严重的河口之一. 本 研究在麦西河河口设 2 个采样点, 采样点 $\mathrm{S} 1$ 位于麦西河的支 流上, 采样点 $\mathrm{S} 2$ 在河口与水库开阔处 (图 1). S1 与 S2 采样点 相差 $2 \mathrm{~km}$ 左右. 为了较好的指导河口水质改善生态工程, 于 2009 年 7 月至 2010 年 6 月工程施工前, 以每月一次的频率采 样调查.

\section{2 实验方法}

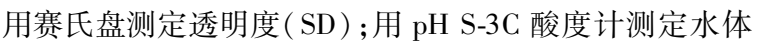
的 $\mathrm{pH}$ 值; 水杨酸法测定铵氮 $\left(\mathrm{NH}_{4}-\mathrm{N}\right)$; 钿酸铵分光光度法测 定总磷 (TP); 碱性过硫酸钾消解-紫外分光光度法测定总氮 $(\mathrm{TN})$; 正磷酸盐 $\left(\mathrm{PO}_{4}-\mathrm{P}\right)$ 和硝氮 $\left(\mathrm{NO}_{3}-\mathrm{N}\right)$ 用 $0.45 \mu \mathrm{m}$ 的纤维滤 膜抽滤后在 24 小时内采用分光光度法测定; 叶绿素 a(Chl. a) 采用经过 $0.45 \mu \mathrm{m}$ 的纤维滤膜抽滤 $200-500 \mathrm{ml}$, 反复冻融后, 丙酮萃取方法进行测定 ${ }^{[14]}$. 浊度 (Tur) 按照国家水质标准方

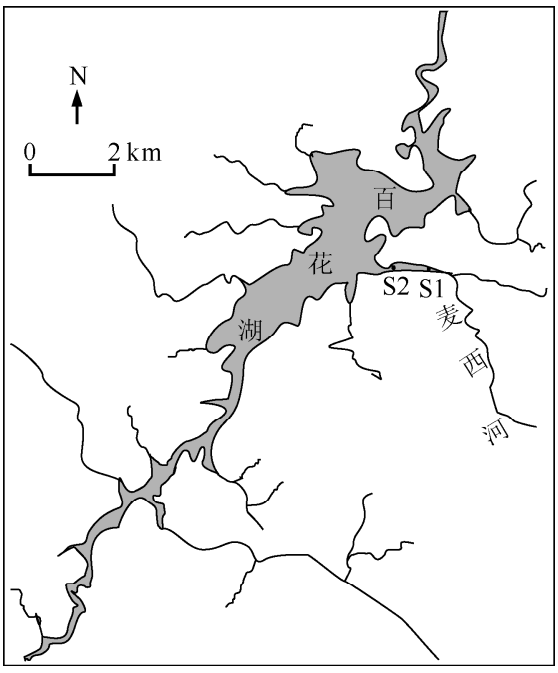

图 1 百花湖 (水库)麦西河口采样点

Fig . 1 Sampling sites at the estuary of

Maixi River in Baihua Reservoir 法 GB 3838-2002 中的分光光度法测定 ${ }^{[15]}$; 浮游植物定量样 品在表层 $0.5 \mathrm{~m}$ 处采 $1-2 \mathrm{~L}$ 水样, 用浓度为 $3 \%-5 \%$ 的福尔马林固定, 在实验室浓缩沉淀. 浮游植物定量样 品在显微镜下进行鉴定和计数, 计数方法采用目镜行格法, 一般随机计数两个垂直行格, 对于生物量较大 而不合适采用行格法的采用视野计数法,一般 30-50 个视野,使得细胞数在 300 个以上. 藻类生物体积根 据各藻类相近几何形状的体积公式计算, 假定浮游植物藻类的密度为 $1.0 \mathrm{~g} / \mathrm{cm}^{3}$, 计算水体浮游植物生 物量 ${ }^{[16]}$.

\section{3 数据分析}

利用 SPSS 15.0 分析环境因子之间的相关关系, 利用 MVSP 软件包进行 CCA 分析. 采用浮游植物丰度 指标来反映浮游植物种类与环境的关系, 为了使浮游植物丰度的数据获得正态分布, 将浮游植物丰度值采 用 $\lg (x+1)$ 进行处理. 浮游植物选择出现频率在 $60 \%$ 以上的种类. 环境因子选择营养盐指标和常见的理化 指标, 如 $\mathrm{TN} 、 \mathrm{TP} 、 \mathrm{NH}_{4}-\mathrm{N} 、 \mathrm{NO}_{3}-\mathrm{N} 、 \mathrm{PO}_{4}-\mathrm{P} 、 \mathrm{SD} 、 \mathrm{pH}$ 值、浊度、温度等 9 个指标. 


\section{2 结果与分析}

\section{1 环境因子}

百花湖 (水库) 麦西河河口 S1 和 S2 采样点的 TN 和 TP 均以冬季 $1-2$ 月浓度最高, 而夏季浓度最低. S1 采样点 2 月份 $\mathrm{TN}$ 浓度最高, 达到 $2.07 \mathrm{mg} / \mathrm{L} ; \mathrm{S} 1$ 采样点 1 月份 $\mathrm{TP}$ 浓度最高, 为 $0.12 \mathrm{mg} / \mathrm{L} ; \mathrm{Chl}$. a 夏季出现最 大值, $\mathrm{S} 1$ 点 Chl. a 最高到达 $120.20 \mu \mathrm{g} / \mathrm{L}$, 而在冬季出现最小值, S2 点 Chl. a 仅为 $2.77 \mu \mathrm{g} / \mathrm{L}$. SD 以 5 月份最 低, 仅 $0.50 \mathrm{~m}$, 而 1 月份最高为 $1.70 \mathrm{~m}$. 高的 TN 和 TP 浓度及 Chl. a 浓度指示出百花湖 (水库) 麦西河河口的 富营养化程度较高, 水环境质量较差, 大部分时期处于富营养化状态. SD 与 TN 的相关关系不强 $(n=24, P>$ $0.1)$, 与其他的环境因子均有较强的相关关系, Chl. a 与 $\mathrm{PO}_{4}-\mathrm{P}(n=24, P<0.05, r=-0.47)$ 和浊度 $(n=24$, $P<0.05, r=0.41)$ 有较好的相关关系, $\mathrm{TN}$ 与 $\mathrm{NO}_{3}-\mathrm{N}(n=24, P<0.05, r=0.50)$ 和浊度 $(n=24, P<0.05, r=$ $-0.48)$ 有较好的相关关系, $\mathrm{pH}$ 值与浊度 $(n=24, P<0.01, r=0.65)$ 和 $\mathrm{NH}_{4}-\mathrm{N}(n=24, P<0.01, r=-0.57)$ 有较强的相关关系 (表 1).

表 1 百花(湖)水库麦西河河口环境因子 $(n=24)$

Tab. 1 The relationship between environmental factors at the estuary of Maixi River in Baihua Reservoir

\begin{tabular}{|c|c|c|c|c|c|c|c|c|}
\hline & $\mathrm{SD}$ & Chl. a & $\mathrm{TN}$ & $\mathrm{TP}$ & $\mathrm{PO}_{4}-\mathrm{P}$ & $\mathrm{NO}_{3}-\mathrm{N}$ & $\mathrm{pH}$ & 浊度 \\
\hline SD & 1 & & & & & & & \\
\hline Chl. a & $-0.52 * *$ & 1 & & & & & & \\
\hline $\mathrm{TN}$ & 0.25 & 0.17 & 1 & & & & & \\
\hline TP & $0.65^{* *}$ & -0.25 & 0.13 & 1 & & & & \\
\hline $\mathrm{PO}_{4}-\mathrm{P}$ & $0.93^{* *}$ & $-0.47^{*}$ & 0.15 & $0.71^{* *}$ & 1 & & & \\
\hline $\mathrm{NO}_{3}-\mathrm{N}$ & $0.79^{* *}$ & -0.35 & $0.50^{*}$ & $0.48^{*}$ & $0.68^{* *}$ & 1 & & \\
\hline $\mathrm{pH}$ & $-0.62^{* *}$ & 0.14 & -0.25 & -0.34 & $-0.60^{* *}$ & $-0.45^{*}$ & 1 & \\
\hline 浊度 & $-0.85^{* *}$ & $0.41 *$ & $-0.48^{*}$ & -0.48 * & $-0.75^{* *}$ & $-0.69^{* *}$ & $0.65 * *$ & 1 \\
\hline $\mathrm{NH}_{4}-\mathrm{N}$ & $0.49^{*}$ & -0.12 & -0.08 & 0.27 & $0.51^{*}$ & 0.22 & $-0.57^{* *}$ & $-0.54^{* *}$ \\
\hline
\end{tabular}

* 代表显著水平 0.05 (双尾检验); **代表显著水平 0.01 (双尾检验).

\section{2 浮游植物}

2.2 .1 浮游植物种类组成 从 2009 年 7 月至 2010 年 6 月对百花湖 (水库) 麦西河河口的 12 次采样调查共

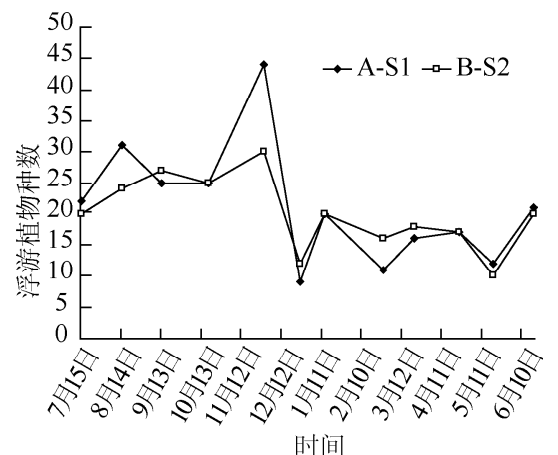

图 2 百花湖麦西河河口浮游植物 种类数动态变化

Fig. 2 Number of phytoplankton species at the estuary of Maixi River in Baihua

Reservoir
监测出浮游植物 66 种 (属), 包括蓝藻 11 种 (属), 绿藻 30 种 (属), 硅藻 16 种 (属), 甲藻 3 种 (属), 裸藻 5 种 (属), 隐藻 1 种 (属). 其中, 11 月份监测出河口浮游植物种类数最多, $\mathrm{S} 1$ 采样 点监测到 44 种 (属), 而 12 月份监测到的浮游植物种类最少, 7-11 月份浮游植物种类数多于 $12-6$ 月, 每次监测浮游植物 种类数在 20 种 (属) 左右. $\mathrm{S} 1$ 点和 $\mathrm{S} 2$ 点浮游植物种类数相差不 大, $\mathrm{S} 1$ 点浮游植物种类数略比 $\mathrm{S} 2$ 点的高 (图 2).

2.2 .2 浮游植物优势藻类及次优势藻 百花湖 (水库) 麦西河河 口主要的优势浮游植物是蓝藻门的湖泊假鱼腥藻 (Pseudanabaena limnetica). 在统计的一个水文年的浮游植物数据中, 有 8 个月是以湖泊假鱼腥藻为优势种 (即 2009 年 7-11 月,2010 年 4-6月), 在冬春季是以硅藻门的梅尼小环藻 (Cyclotella meneghiniana) 为主要优势种. 水库以蓝藻门中的针晶蓝纤维藻 (Dactyloccopsis rhaphidioide)、湖丝藻 (Limnthriox redekei)、林氏藻 (Lyngbya sp.) 、肘状针杆藻 (Synedra ulna) 、小球藻 (Chlorella vul- 
garis)、多甲藻 (Peridinium sp. ) 、囊裸藻 ( Trachelomononas sp.) 为常见种.

2.2.3 浮游植物丰度的动态变化 在 $\mathrm{S} 1$ 采样点浮游植物 丰度在 $8.07 \times 10^{4}-3.35 \times 10^{7}$ cells $/ \mathrm{L}$ 之间, 而 $\mathrm{S} 2$ 采样点 在 $1.17 \times 10^{4}-2.44 \times 10^{7}$ cells $/ \mathrm{L}$ 之间. S1 和 S2 采样点有 相同的变化趋势, 但是 $\mathrm{S} 1$ 采样点浮游植物丰度要高于 $\mathrm{S} 2$ 采样点. S1 采样点以 2009 年 7 月最高为 $3.35 \times 10^{7}$ cells/ $\mathrm{L}$, 而 $\mathrm{S} 2$ 采样点以 2009 年 9 月最高为 $2.44 \times 10^{7}$ cells $/ \mathrm{L}$ (图 3). 在 5-10 月浮游植物丰度较高, 由此可见, 在夏季 7-9 月份最容易形成水华, 水体富营养化程度也较高.

2.2 .4 浮游植物各门类丰度组成 $\mathrm{S} 1$ 采样点和 S2 采样 点浮游植物各门类丰度组成相似. 2009 年 7-9 月和 2010 年 4-6月, 浮游植物主要由湖泊假鱼腥藻组成, 蓝藻成 为浮游植物群落中相对丰度最高的门类. 而在冬季和早 春 (11-4 月), 以硅藻门的梅尼小环藻和甲藻门的多甲 藻为主要种类 (图 4).

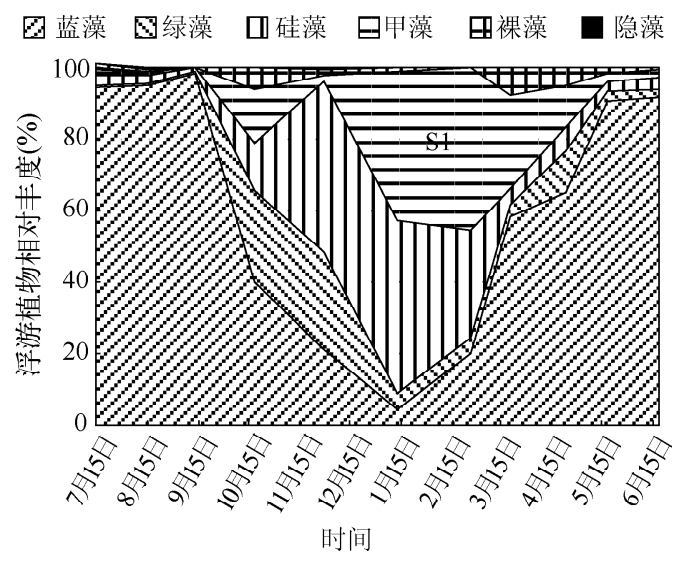

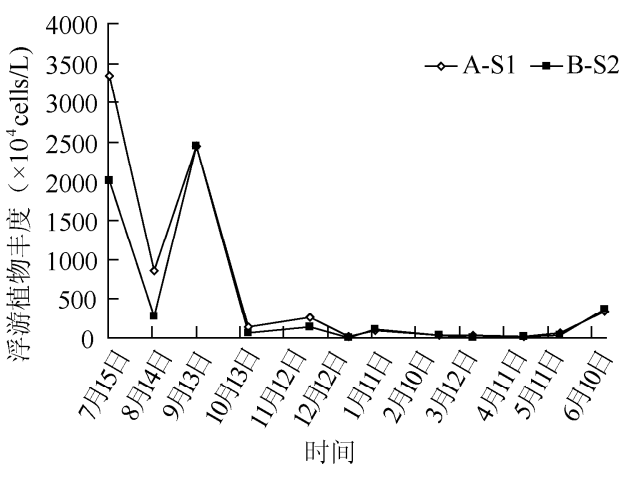

图 3 百花湖 (水库) 麦西河河口浮游植物 丰度季节动态变化

Fig. 3 Seasonal variation of phytoplankton abundance at the estuary of Maixi River in Baihua Reservoir

图 4 百花湖 (水库) 麦西河河口浮游植物各门类相对丰度季节动态变化

Fig. 4 Seasonal variation of relative phytoplankton abundances of different phylums at the estuary of Maixi River in Baihua Reservoir

2.2 .5 浮游植物生物量的动态变化 在 $\mathrm{S} 1$ 采样点, 浮游植物生物量在 $0.424-14.590 \mathrm{mg} / \mathrm{L}$ 之间, 而 $\mathrm{S} 2$ 采样 点在 $0.144-7.535 \mathrm{mg} / \mathrm{L}$ 之间. S1 和 S2 采样点有相同的变化趋势, 但是 S1 采样点浮游植物生物量要高于 S2 采样点. $\mathrm{S} 1$ 采样点浮游植物生物量以 2009 年 7 月最高, 为 $14.590 \mathrm{mg} / \mathrm{L}$; 而 $\mathrm{S} 2$ 采样点以 2010 年 2 月最高, 为 $7.535 \mathrm{mg} / \mathrm{L}$. 从浮游植物各门类的生物量的组成可以看出, 在夏季 ( 7-10 月) 主要由蓝藻组成, 而在冬季 (12-3 月) 主要由硅藻和甲藻组成( 图 5).

2.2.6 浮游植物与环境因子之间的 CCA 分析 根据浮游植物丰度和出现的频率, 分别选取约 30 种浮游植 物, 其丰度占整个水库浮游植物丰度的 $98 \%$ 以上 (表 2 ). 轴 1 特征值、贡献的百分数都比轴 2 的要高. 在浮 游植物种类与环境因子之间的相关系数中, 可以看到各点轴 1 和轴 2 的相关性都很高, 在 S1 和 S2 采样点, 轴 1 和轴 2 浮游植物种类与环境因子的相关性在 0.95 以上. 表明在 $\mathrm{S} 1$ 采样点, 浊度、 $\mathrm{TN}$ 、温度是影响浮游 植物种类组成和分布的主要环境因子; 而在 $\mathrm{S} 2$ 采样点, 温度、 $\mathrm{PO}_{4}-\mathrm{P} 、 \mathrm{SD} 、 \mathrm{TP}$ 和 $\mathrm{pH}$ 值是影响浮游植物种类组 成和分布的主要环境因子. $S 1$ 和 $S 2$ 采样点虽然距离不远,但影响浮游植物组成的主要环境因子有区别. 在 S1 和 S2 采样点影响浮游植物最关键的环境因子都是温度, 因而温度成为影响贵州高原水体浮游植物群 

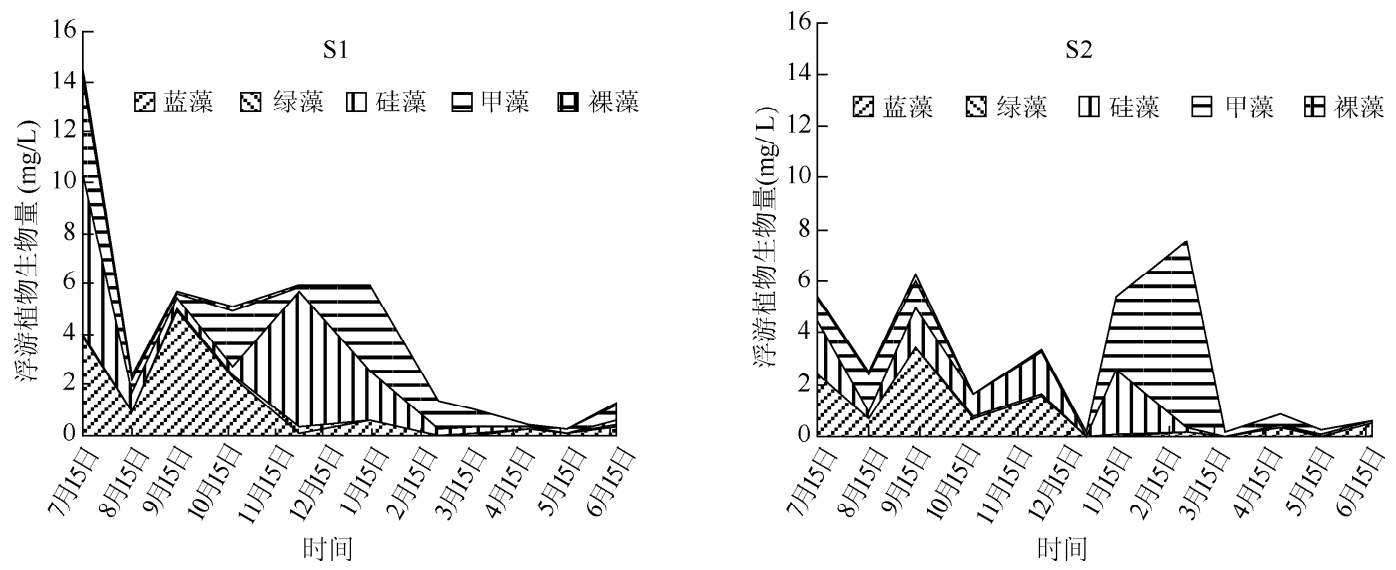

图 5 百花湖 (水库) 麦西河河口浮游植物各门类生物量季节动态变化

Fig. 5 Seasonal variation of phytoplankton biomass of different phylums at the estuary of Maixi River in Baihua Reservoir

落结构动态变化的最主要环境 因子.

在 $\mathrm{S} 1$ 采样点, 蓝藻的大部分种 类和裸藻受到温度和水体浊度的影 响最大,而硅藻和绿藻的大部分种类 受到氮磷营养盐浓度的影响; S2 采 样点和 $\mathrm{S} 1$ 采样点相似,水体中大部 分的蓝藻种类受到水体浊度和温度 等影响, 而其它藻类如绿藻、硅藻和 裸藻受到 $\mathrm{NO}_{3}-\mathrm{N}$ 和 $\mathrm{PO}_{4}-\mathrm{P}$ 的影响 (图 $6)$.
表 2 百花湖 (水库)麦西河河口浮游植物群落 CCA 分析的统计信息

Tab. 2 Statistics for the first two axes of CCA performed on the estuary of Maixi River in Baihua Reservoir

\begin{tabular}{lrrrrrr}
\hline \multirow{2}{*}{ 统计信息 } & \multicolumn{2}{c}{ 采样点 $\mathrm{S} 1$} & & \multicolumn{2}{c}{ 采样点 $\mathrm{S} 2$} \\
\cline { 2 - 3 } & 轴 1 & 轴 2 & & 轴 1 & 轴 2 \\
\hline 特征值 & 0.142 & 0.129 & & 0.279 & 0.141 \\
百分数 & 20.764 & 18.731 & & 27.352 & 13.850 \\
特征值累计百分数 & 20.764 & 39.495 & & 27.352 & 41.203 \\
方差累计贡献百分数 & 23.724 & 45.127 & & 32.547 & 49.028 \\
浮游植物种类与环境因子相关性 & 1 & 0.997 & & 0.983 & 0.984 \\
\hline
\end{tabular}

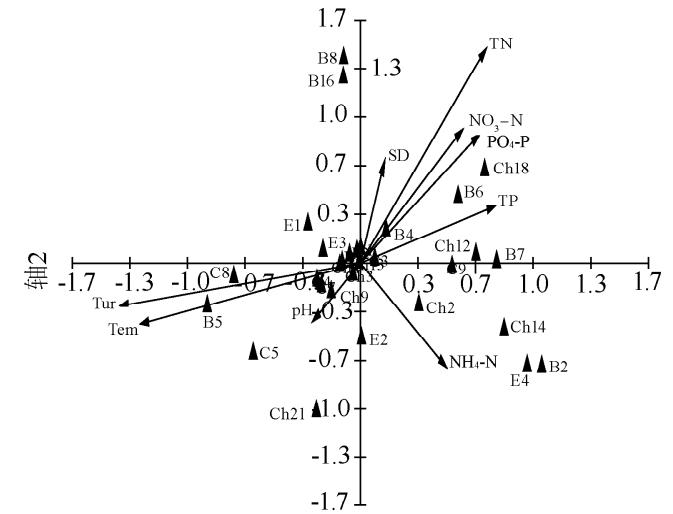

轴1

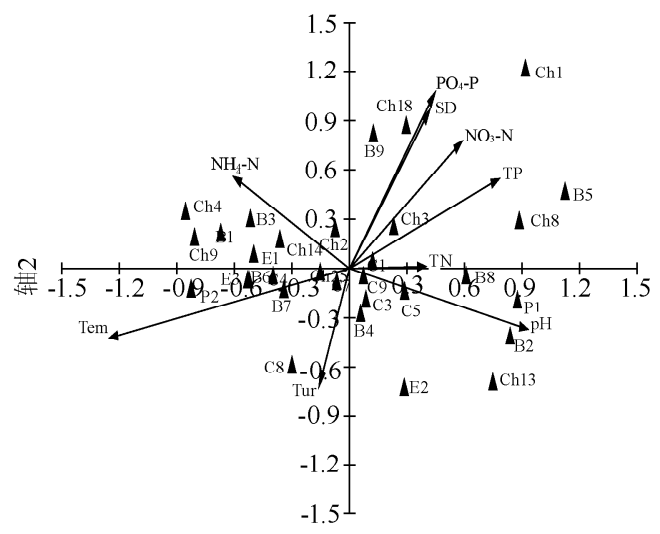

轴1

图 6 百花湖 (水库) 麦西河河口浮游植物种类与环境因子之间的双轴等级排列 (C1-C11 代表蓝藻门种类;

Ch1-Ch30 代表绿藻门种类;B1-B16 代表硅藻门种类;P1-P3 代表甲藻门种类;E1-E5 代表裸藻门种类; $\mathrm{Cr} 1$ 代表隐藻门种类)

Fig. 6 Ordination biplots of species and environmental variables at the estuary of Maixi River in Baihua Reservoir 


\section{3 讨论}

\section{1 百花湖 (水库) 麦西河河口水质状况}

百花湖麦西河河口在水文年内 TN 平均值为 $1.42 \mathrm{mg} / \mathrm{L}$, 其中 $\mathrm{S} 1$ 采样点 TN、TP、Chl. a 的平均值分别为 $1.46 \mathrm{mg} / \mathrm{L} 、 0.081 \mathrm{mg} / \mathrm{L}$ 和 $52.15 \mu \mathrm{g} / \mathrm{L}, \mathrm{S} 2$ 采样点 $\mathrm{TN} 、 \mathrm{TP} 、 \mathrm{Chl} . \mathrm{a}$ 的平均值分别为 $1.39 \mathrm{mg} / \mathrm{L} 、 0.085 \mathrm{mg} / \mathrm{L}$ 和 36. $74 \mu \mathrm{g} / \mathrm{L}$, 根据 GB 3838-2002 地表水环境质量标准, 以 TN、TP 及 Chl. a 的含量来评价的麦西河河口的水 质为 IV 类. N/P 比在 $14-48$, 大部分时期 N/P 比超过 16 , 可见百花湖麦西河河口是属于磷限制的水体. 富营 养状态指数采用修正的卡尔森指数方法进行计算 ${ }^{[17]}$, 百花湖麦西河河口富营养化指数在 38.8-55.4 之间, 最大值出现在 7 月份 $\mathrm{S} 1$ 采样点, 最小值出现在 12 月份 $\mathrm{S} 2$ 采样点; 平均富营养化指数为 50.4 , 这也表明了 百花湖麦西河河口富营养化程度较高, 大部分时期处于富营养化状态, 尤其以夏季和秋季富营养化更为严 重. 从浮游植物丰度值来看, 夏季和秋季河口浮游植物丰度较高, 富营养化程度也较高, 该时期发生水华的 可能性也较大,这段时期应该加强水质管理.

\section{2 百花湖 (水库) 麦西河河口浮游植物群落结构与环境因子之间的关系}

水库作为一个受人工调节程度很高的水体, 其浮游植物动态在很大程度上与水动力学有关 ${ }^{[18-20]}$, 但不 同水体具有不同主要影响因子. 河口不同于湖泊、水库和河流,污染物相对比较集中,水动力学条件变化大, 浮游植物群落结构在各点差异较大. 虽然 $\mathrm{S} 1$ 与 $\mathrm{S} 2$ 距离 $2 \mathrm{~km}$ 左右, 浮游植物优势种类相同, 丰度变化趋势一 致,但是浮游植物丰度值不同, 主要由水力条件和水质状况不同引起的, $\mathrm{S} 1$ 采样点更远离水库开阔区, 水体 深度也较 S2 浅, 水体的富营养化指标及富营养化指数均高于 S2 采样点. 百花湖 (水库) 麦西河河口浮游植 物群落的种类组成相对稳定, 优势种类单一, 以蓝藻中的湖泊假鱼腥藻为主要优势藻类, 这一特征也与热带 亚热带水库/湖泊浮游植物生态特征的表现相同 ${ }^{[11,22]}$, 明显有别于温带水体 ${ }^{[21]}$. 在 S1 采样点浊度、TN、温度 是影响浮游植物种类组成和分布的主要环境因子; 在 $\mathrm{S} 2$ 采样点, 温度、 $\mathrm{PO}_{4}-\mathrm{P} 、 \mathrm{SD} 、 \mathrm{TP}$ 和 $\mathrm{pH}$ 值是影响浮游植 物群落结构动态变化的主要环境因子. 温度是影响 S1 和 S2 采样点浮游植物群落结构的主要环境因子, 营 养盐成为影响浮游植物群落结构动态变化的次要环境因子 ${ }^{[18]}$. 在河口浮游植物与环境因子关系的研究中, 黄小平等发现河口最大浑浊带的湍流混合过程增大了浮游植物细胞光合作用的机会, 重力环流致使浮游植 物及其光合作用所需的物质能较长时间停留 ${ }^{[23]}$, 认为浑浊度对浮游植物的影响较大, 对比本文的研究, 浑浊 度也是影响浮游植物群落结构动态变化的主要环境因子之一, 尤其是在 S1 采样点. 在许多的水体中, 温度 是影响浮游植物生长和群落结构的最主要环境因子 ${ }^{[24-25]}$, 如广东的大镜山水库 ${ }^{[11]}$ 、巢湖 ${ }^{[12]}$ 和洪湖 ${ }^{[13]}$ 等, 本 文也得到了相似的结论.

\section{4 参考文献}

[ 1 ] Reynolds CS. The ecology of freshwater phytoplankton. Cambridge: Cambridge University Press, 1984.

[ 2 ] Habib OA, Tippett R, Murphy KJ. Seasonal changes in phytoplankton community structure in relation to physico-chemical factors in Loch Lomond, Scotland. Hydrobiologia, 1997, 350 : 63-79.

[ 3 ] 郭沛勇,沈焕庭. 河口浮游植物生态学研究进展. 应用生态学报,2003,14(1):139-142.

[ 4 ] 林秋奇, 胡 韧, 韩博平. 流溪河水库水动力学对营养盐和浮游植物分布的影响. 生态学报, 2003, 23 (11): 2278-2284.

[ 5 ] Pilkaitytè R, Razinkovas A. Factors controlling phytoplankton blooms in a temperate estuary: nutrient limintation and physical forcing. Hydrobiologia, 2006, 555: 41-48.

[ 6 ] Singh PK, Malik A, Mohan D et al. Multivariate statistical techniques for the evaluation of spatial and temporal variations in water quality of Gomti River(India) -a case study. Water Research, 2004, 38 : 3980-3992.

[ 7 ] Camdevyren H, Demyr N, Kanik A et al. Use of principal component scores in multiple linear regression models for prediction of Chlorophyll-a in reservoirs. Ecological Modelling, 2005, 181 : 581-589.

[ 8 ] Naselli-Flores L, Barone R. Phytoplankton dynamics in two reservoir with different trophic state ( Lake Rosamarina and Lake Arancio, Sicily, Italy). Hydrobiologia, 1998, 369-370 : 163-178.

[ 9 ] Naselli-Flores L. Phytoplankton assemblages in twenty-one Sicilian reservoirs: relationship between species composition and 
environmental factors. Hydrobiologia, $2000,424: 1-11$.

[10] Komárková J, Komárek O, Hejzlar J. Evaluation of the termmonitoring of phytoplankton assemblages in a cyanyon-shape reservoir using multivariate statistical methods. Hydrobiologia, 2003, 504: 143-157.

[11] 李秋华,韩博平. 基于 CCA 的典型调水水库浮游植物群落动态特征分析. 生态学报,2007,27(6):2355-2364.

[12] 路 娜, 尹洪斌, 邓建才等. 巢湖流域春季浮游植物群落结构特征及其与环境因子之间的关系. 湖泊科学, 2010,22 (6) :950-956.

[13] 邓建明,蔡永久,陈宇炜等. 洪湖浮游植物群落结构及其与环境因子之间的关系. 湖泊科学, 2010,2 (1):70-78.

[14] 林少君,贺立静,黄沛生等. 浮游植物中叶绿素 a 提取方法的比较与改进. 生态科学,2005,24(1):9-11.

[15］金湘灿,屠清瑛. 湖泊富营养化调查规范. 北京: 中国环境科学出版社, 1990.

[16] 章宗涉,黄祥飞. 淡水浮游植物研究方法. 北京:科学出版社,1991.

[17] Lin QQ, Han BP, Lin QX et al. Rervoir water supply and eutrophication in Guangdong province( South China). In: International lakes environment committee ed. Proceedings of 9th international conference on the conservation and management of lakes. Shiga, $2001: 269-272$.

[18 ] Arfi R. The effects of climate and hydrology on the trophic status of Sélingué Reservoir, Mali, West Africa. Lake and Resevoir : Research and management, 2003,8 : 247-257.

[19] Horn H. The relative importance of climate and nutrients in controlling phytoplankton growth in Saidenbach Reservoir. Hydrobiologia, 2003, 504: 159-166.

[20] Gomes LC, Miranda LE. Hydrologic and climatic regimes limit phytoplankton biomass in reservoirs of the Upper Paraná River Basin, Brazail. Hydrobiologia, 2001, 457: 205-214.

[21] Kotou K, Krientz L, Muthuri FM. Temporal changes in phytoplankton structure and composition at the Turkwel Gorge reservoir, Kenya. Hydrobiologia, 1998, 368: 41-59.

[22] 李秋华, 韩博平. 南亚热带调水水库春季浮游植物群落的结构与动态. 热带亚热带植物学报, 2007, 15 (4): 294-300.

[23] 黄小平, 黄良民. 河口最大浑浊带浮游植物生态动力过程研究进展. 生态学报,2002,22(9):1527-1533.

[24] Mayer J, Dokulil MT, Salbrechter M et al. Seasonal successions and trophic relations between phytoplankton, zooplankton, ciliate and bacteria in a hypertrophic shallow lake in Vienna, Austria. Hydrobiologia, 1997, 342/343 : 165-174.

[25] Koch RW, Guelda DL, Bukaveckas PA. Phytoplankton growth in the Ohio, Cumberland and Tennessee Rivers, USA: inter-site difference in light and nutrient limitation. Aquatic Ecology, 2004, 38: 17-26. 